\title{
PRODUCING NEW SPATIAL(IZED) (HI)STORIES ON CONGOLESE CITIES: REFLECTIONS ON TEN YEARS OF COLLABORATION BETWEEN UGENT AND UNIKIN
}

\begin{abstract}
Johan Lagae
Department of Architecture and Urban Planning, Ghent University, Belgium

Former vice-president of the Ghent Africa Platform (GAP)

Jacob Sabakinu Kivilu

History Department, University of Kinshasa, Democratic Republic of Congo

This article presents the context and some of the results of ten years of collaboration in the field of African urban history between researchers from Ghent University (UGent), and mainly its Department of Architecture and Urban Planning, and scholars of the Université de Kinshasa (UNIKIN), which, in part, has benefited from the forum created by the Ghent African Platform (GAP). What ties together this collaborative work, is the conviction that 'History matters' when thinking not only about the past, but also about the present and the future of cities in today's DR Congo. Moreover, we argue, it is the combination of our complementary expertise in socio-demographic history and architectural/ urban planning history that has enabled us to develop new narratives on space and society in these urban environments. These, we believe, hold a relevance for the historiography of Congo's colonial past as well as for current discussions on colonial heritage and urban development. By demonstrating that we have gained much through stimulating a cross-disciplinary and inter-generational conversation that brings together (the expertise from) scholars working on Congo/Africa and coming from different backgrounds, academic cultures and age, we explicitly want to advocate setting up forms of relationship between the 'North' and 'South' that go beyond the common trope of 'Capacity Building'. A number of specific pieces of work related to the cities of Kinshasa and Matadi will be discussed, illustrating how we have also deliberately sought to target different audiences by producing different kinds of output, from academic publications to exhibitions, reports for policy makers to outreach activities in the cultural arena. As such, we believe that this ten years of collaboration on African Urban History is fully in tune with GAP's main agenda of creating a cross-disciplinary forum where scholars from North and South, and from different generations can meet and exchange ideas, and we hope to embed our future collaboration in an even broader community, both at UGent and UNIKIN.
\end{abstract}

KEYWORDS: DR CONGO, URBAN HISTORY, CROSS-DISCIPLINARITY, COLLABORATIVE RESEARCH

\section{A fruitful (first) encounter}

In August 2007, the Ecole de médecine of the Université de Kinshasa (UNIKIN) formed the stage for an international workshop entitled 'Sites, Sights and Spaces. New methodolo- 
gies in the historiography of cities in the Congo (DRC)'. Over the course of five days, a group of almost 6o people from eight different countries (DR Congo, South Africa, Senegal, Angola, Belgium, UK, France and the US), coming from various disciplinary backgrounds and academic cultures, was engaged in often lively debates on a number of issues related to the broader field of African urban history: ${ }^{\mathrm{I}}$ Sessions dealt with topics such as colonial built heritage as well as with spaces of the marginalized/marginal spaces in the city over time; the potential of using visual sources such as photographs and maps was addressed, as well as drawing on oral history and on innovative anthropological readings of the city. At the heart of the discussion was the question of why 'history matters' when thinking of African/Congolese cities. It was a shared belief in the importance of new historical perspectives when thinking not only about the past, but also about the present and the future of cities like Kinshasa that triggered both authors of this article to organize this workshop, together with colleague and renowned Congo-scholar Nancy Rose Hunt (Hunt, I999).

It was Jean-Luc Vellut from the Université Catholique de Louvain, the internationally esteemed, yet in Belgium still somewhat underrated historian of Congo's colonial past (Vellut, 2017; Etambala \& Mabiala, 20I6), who had brought the three of us together a couple of years before, when he was acting as the main scientific curator in the preparation of the exhibition The Memory of Congo. The colonial era would open its doors in February 2005 in the Royal Museum for Central Africa, Tervuren (Vellut, 2005). Johan Lagae was invited by Vellut in 2003 to become member of the core curatorial team because of his $\mathrm{PhD}$ on colonial architecture in Congo (Lagae, 2002), and was responsible for, among other things, for introducing spatial and visual urban history as a new way of looking at Congo's colonial past (Lagae, 2015). Jacob Sabakinu Kivilu served as president of the scientific committee of the exhibition and hosted Vellut and Lagae on a prospection mission to Kinshasa in 2003. Nancy Hunt was brought in by Vellut as one of the external consultants and participated in some of the round table discussions in the early phase of mounting the project.

The 2007 UNIKIN-workshop on Urban History was a direct result of that earlier encounter which had made us aware of a shared interest in Congo's colonial history and in the vibrancy of a city like Kinshasa. The three of us felt that it was timely to start a cross-disciplinary and inter-generational conversation of how to engage with Congo's cities, an engagement that would draw on recent developments in the broader domains of both African Studies and of African Urban History in particular (e.g. Coquery-Vidrovitch, I993; Anderson \& Rathbone, 2000; Salm \& Falola, 2005; Freund, 2007). Moreover, we shared the conviction that it was crucial to stage this conversation not in Belgium, but in Congo. By bringing insights from other places and academic culture to DR Congo and engaging with local scholarship and ongoing debates in Congolese academic circles, an important underlying idea of the UNIKIN-workshop, even if we might never have articulated it explicitly as such, was underlined, that we wanted to create an encounter that would go

I The international workshop took place from I7 to 2I September 2007. It was made possible through an INCO-grant of the VLIR-UOS, with additional financial support from UGent, UNIKIN and the KULeuven. 

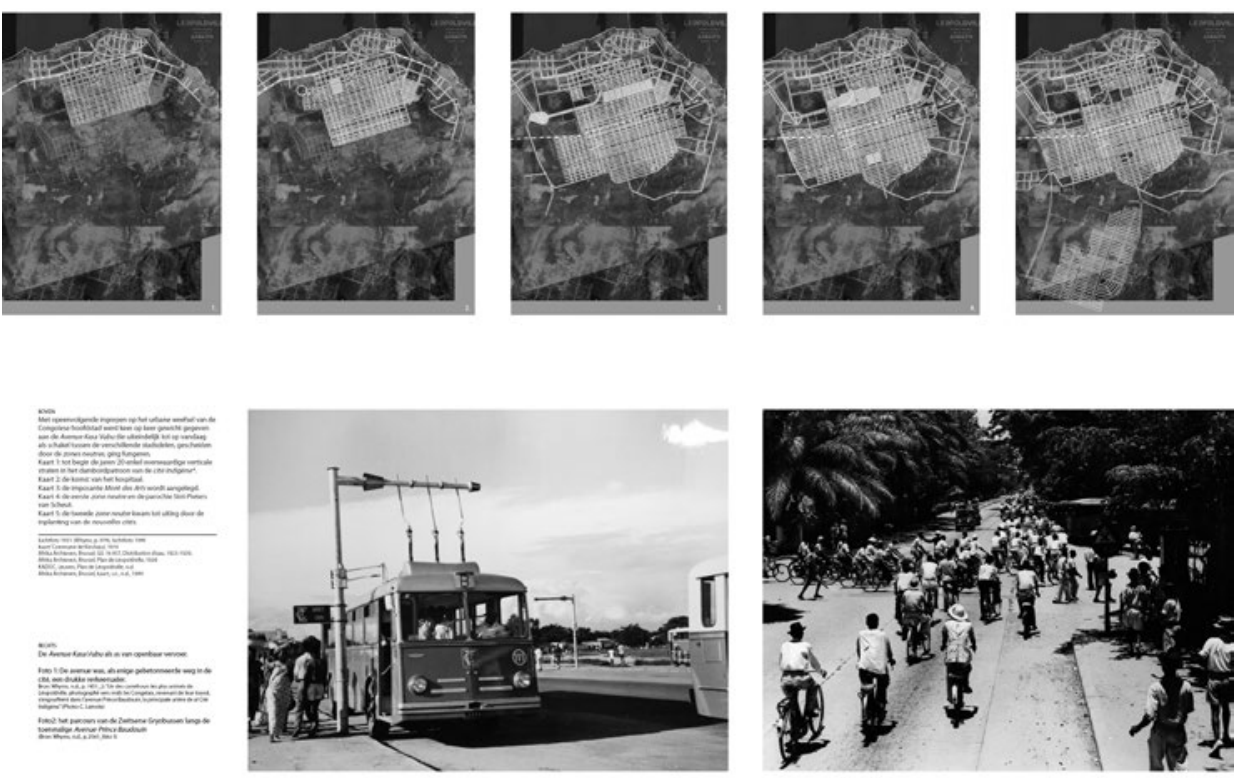

Figure 1: An overview of the spatial development of Kinshasa, in 5 steps from the 1920s till the 1950s. The Avenue Kasa Vubu acts as the main axis linking the postwar cités (in the south) to the city center (in the north), along which the mobility of the African population was made possible in the 1950 s via a bus transport system and the massive distribution of bicycles. Pages from Kennive $\&$ Van Coster, 2012: 54-55

beyond the trope of 'Capacity Building' and in which everyone involved would have his/ her say on an equal basis. In the beginning, this somewhat implicit agenda created quite some disciplinary miscommunication and even misunderstandings as well as some friction between different generations of junior and senior scholars, in particular with regard to methodological questions. But over the course of five days of work and discussion, we nevertheless succeeded in triggering a very open-minded and engaged conversation. As a result, the workshop became an important moment for many of the participants. Even if no publication resulted from the 2007 UNIKIN-workshop, the intensity of the discussions and the commitment of all participants, did create a number of very tangible outcomes in the form of a number of collaborations, some of which continue today. ${ }^{2}$

For the two authors of this article, the UNIKIN-workshop marked the beginning of a long lasting collaboration on the urban history of cities such as Kinshasa and Matadi, in which a number of people of both the UGent Department of Architecture and Urban Planning

2 In fact, some of the participants met again recently in Florida in 20I8, at the invitation of Nancy Rose Hunt, albeit in the context of a quite different Congo-related project. From the UGent perspective, the workshop was important for establishing a link between Luce Beeckmans from the Department of Architecture and Urban Planning with prof. Ibrahima Thioub at his team at the Université de Cheikh Anta Diop in Dakar, Senegal, first in the context of a Phd research (Beeckmans, 2013) and, later, via the work conducted by UGent master students on the SICAP-housing scheme in Dakar, which will result in a book project. 


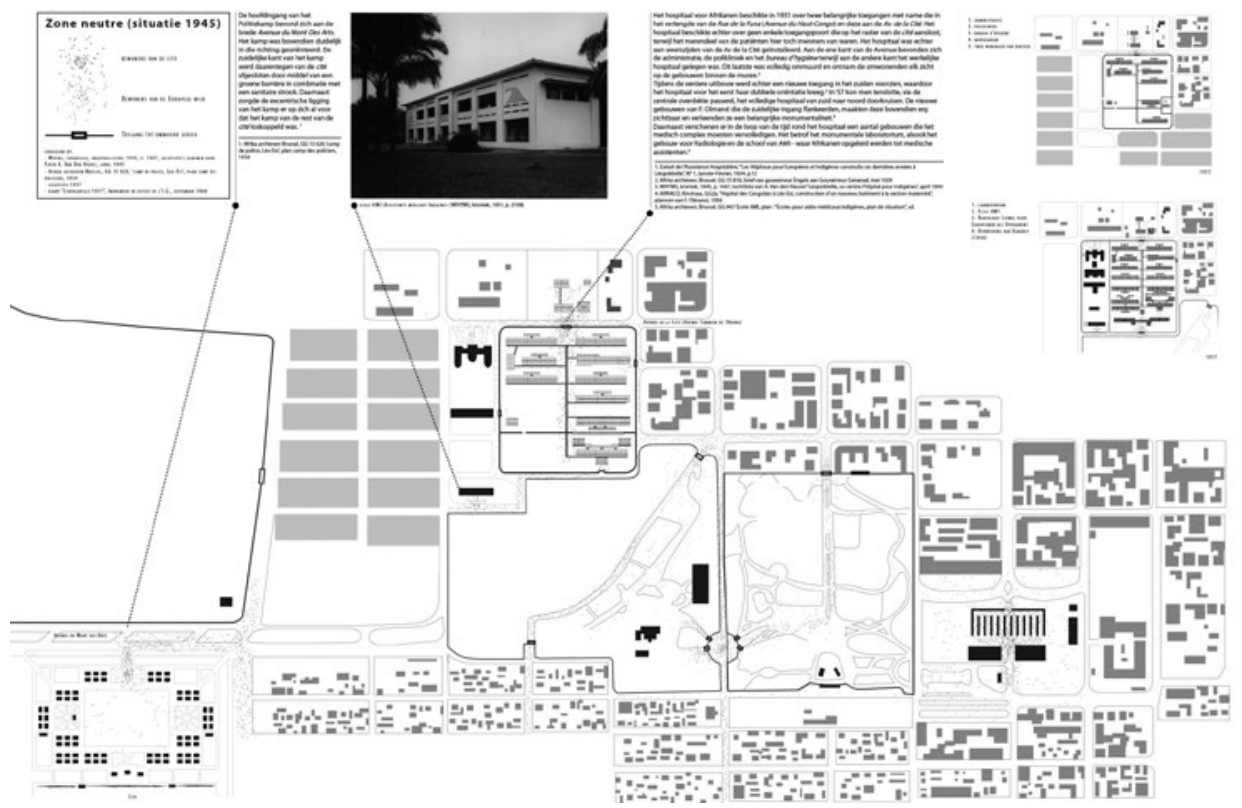

Figure 2: A detailed mapping of Kinshasa's "zone neutre" (i.e. a series of "zones tampons" separating the "ville européenne" from the "cite indigène"), with an indication of the Hôpital Mama Yemo, the hospital for Africans which ended up being situated on the "wrong side" of the "buffer zone", in the European part of town. Pages from Kennivé \& Van Coster, 2012: 34-35.

and various departments of the UNIKIN, in particular the History Department, were involved over the years. ${ }^{3}$ At some point, the Ghent Africa Platform (GAP) helped to create openings for a more cross-disciplinary conversation at UGent, and Lagae's role as vicepresident of GAP encouraged him to make contacts beyond the boundaries of his own faculty when setting up research with Sabakinu. Baz Lecocq, during his UGent-mandate as professor of African history, and anthropologist Koen Stroeken both participate(d) in FWO-funded research projects, and, more recently, postdoc-researcher and historian Gillian Matthys, was involved in some funding applications. But it should be acknowledged that we have perhaps not yet realised the full potential of the GAP-platform. In the future more could and should be done, especially given that the work of some colleagues in fields such as Conflict and Development Studies, as well as the large fieldwork expertise in Africa/Congo of scholars coming from the fields of Medicine and Law, could actually be very useful for some of our ongoing projects, as the last GAP-symposium in December 2017 revealed.

At UGent, the following members of Lagae's research unit have been involved in the conversation: postdoc researchers Luce Beeckmans (since 2007) and Kristien Geenen (2015-2016); Phd candidates Kim De Raedt, Sofie Boonen, Simon De Nys-Ketels, Robby Fivez; and a number of master students who produced master dissertations on Congo-related topics (see below) or participated in research seminars. On the UNIKIN side, important interlocutors have been professors Isidore Ndaywel è Nziem, Jean-Marie Mutamba, Pamphile Mabiala, Elikia M’Bokolo, Léon Tsambu and assistants Dodo Mukwema, Nephtali Fofolo and Yok Bakwey. 
The conversation that was stimulated by the 2007 UNIKIN-workshop between the two authors of this article has led over the last ten years to a series of outcomes in the form of publications and exhibitions directly related to the field of African urban history, some of which we will discuss below. But it also informed other projects beyond this disciplinary domain. The Congo belge (en images)-book and exhibition project, initiated by Magnumphotographer Carl De Keyzer in collaboration with Johan Lagae and first shown in January 2010 at the Museum of Photography in Antwerp (FoMU), is a case in point. In fact, both Sabakinu and Patricia Hayes, a South African based visual historian who also participated in the UNIKIN-workshop, were invited to bring their voice to the project and thus played a major role in contextualizing the a-typical and often un-settling selection of late $19^{\text {th }}$ and early $20^{\text {th }}$ century photographs presented in the show/catalogue (De Keyzer \& Lagae, 20I0; Lagae, 20I2).

\section{Thinking about space and people in cities}

Belonging to different scholarly generations, both authors come to the field of African Urban History from different disciplinary backgrounds and academic cultures. Sabakinu ( ${ }^{\mathrm{I}}$ 945) was trained as a historian at the Universities of Kinshasa and Lubumbashi in the late I96os and I970s, being versed on the one hand in the tradition of quantitative, sociodemographic research in line with the work of Léon De Saint-Moulin (De Saint-Moulin, 20Io; Sabakinu \& Obotela, forthcoming), and, on the other, in the approach of tracing and close-reading (early) historical local sources which was introduced in Congo's academic circles by historians such as François Bontinck, Jean-Luc Vellut and Bogumil Jewsiewicki (Mabiala, 2004; Vellut, 1974). While he has worked extensively on the history of medicine in colonial and postcolonial Congo (e.g. Sabakinu, I984; 1990), an interest he shares with the above mentioned Nancy Hunt, Sabakinu had from an early stage, a keen interest in urban history. In I98I, he obtained his $\mathrm{PhD}$ with a dissertation on Matadi in which he presented an in depth reading of the port city's changing urban society through analyzing its shifting demographic constellation (Sabakinu I98I). At the center of this research was the question of how a socio-economic inquiry could help shed light on strategies of urban governance, including aspects of violence and segregation, and on tensions among the city's inhabitants.

Graduating as an engineer-architect in I99I, Lagae ( $\left.{ }^{\circ} \mathrm{I} 968\right)$ initially conducted architectural history research on Congo in the context of his Phd on Belgian colonial architecture (2002). This early work was very much informed by the early I9gos 'postcolonial turn' in architectural history and how the work of authors like Gwendolyn Wright or Zeynep Çelik urged scholars to engage with the 'Politics of Design' in colonial contexts (Wright, I99I, Çelik, I997). But he quickly developed a broader interest in a spatial reading of Congolese cities, including the analysis of the evolution of urban form and urban landscapes beyond individual buildings, not only in order to contribute to a rewriting of the history of $20^{\text {th }}$ century Belgian (and global) architecture but also, and more importantly, to gain a more nuanced understanding of Congo's colonial past. In his more recent work there is a focus on the agency of other, often overlooked actors that made and shaped the colonial/postco- 
lonial city, such as the more anonymous bureaucrats of the Public Works Departments or middle figures in urban society, a topic which he first explored in a visual history-project on the city of Boma he developed for the 2005 Tervuren exhibition (Lagae et al., 2005).4 This Boma-project was one of the catalysts behind our discovery of a shared interest in urban history, and of the possibilities of combining our expertise in socio-economic history and architectural/urban history. What brings our work together across our respective disciplines, then, is the conviction that, as Anthony D. King, a pioneer in the study of colonial cities, once articulated, "how people build affects how people think [at least as much as] how people think governs how people build." (King, I984: 99). Or, to put it differently, what is really at the heart of our collaborative work is an interest in the "urban process", a notion that architectural historian Spiro Kostoff coined and that can be defined as "that intriguing conflation of social, political, technical and artistic forces that generates a city's form" (Kostoff, I992).

\section{Collaborating through a cross-disciplinary and inter-generational conversation}

In the aftermath of the UNIKIN-workshop, Sabakinu became involved as a consultant in Luce Beeckmans' $\mathrm{PhD}$ on colonial and postcolonial urban planning in Africa of which Lagae was a co-supervisor (Beeckmans 2013). But the first long lasting and more mutual collaboration was initiated two years later, in 2009, with a research project entitled "City, architecture and colonial space in Matadi and Lubumbashi, Congo. A historical analysis from a translocal perspective", for which Sabakinu acted as a co-supervisor (FWO Go78609N, 2009-2012). The Lubumbashi-part of the research has drawn to a large extent on a collaboration with historian Donatien Dibwe, professor at the Université de Lubumbashi (UNILU), who was also one of the participants in the 2007 UNIKIN-workshop. It has led to a series of master dissertations (Boonen, 2009; Fenaux, 20I0; De Nys-Ketels, 20I2), numerous articles (e.g. Lagae et al., 20I3; Boonen \&Lagae, 2015a; Boonen \& Lagae, 2015b; Lagae et al., 20r6a) and a PhD dissertation which will soon be submitted (Boonen, 2019). Moreover, this historical research was quickly picked up by the local artistic scene in Lubumbashi and resulted in a series of very stimulating forms of exchange and collaborations with artists such as Sammy Baloji and Patrick Mudekereza, continuing till today (Njami 20I2; Mudekereza, 20I7; Baloji 20I8).

In the context of this FWO-funded project, we collaborated mainly on the Matadi-section, in an explicit attempt to complement Sabakinu's I98I socio-demographic PhD research with an in depth analysis of the port city's urban form and spatial development. This project proved more labor intensive than originally anticipated, also because several other opportunities to collaborate came our way. Nevertheless, as we will discuss below, some intermediate outcomes on our Matadi-research were already produced in $201 \mathrm{I}$ and the main research outcome is now in a final stage of completion.

If this first long term collaboration proved fruitful in terms of a cross-disciplinary approach, it was also instructive with regards to the benefits one can draw from an inter- 


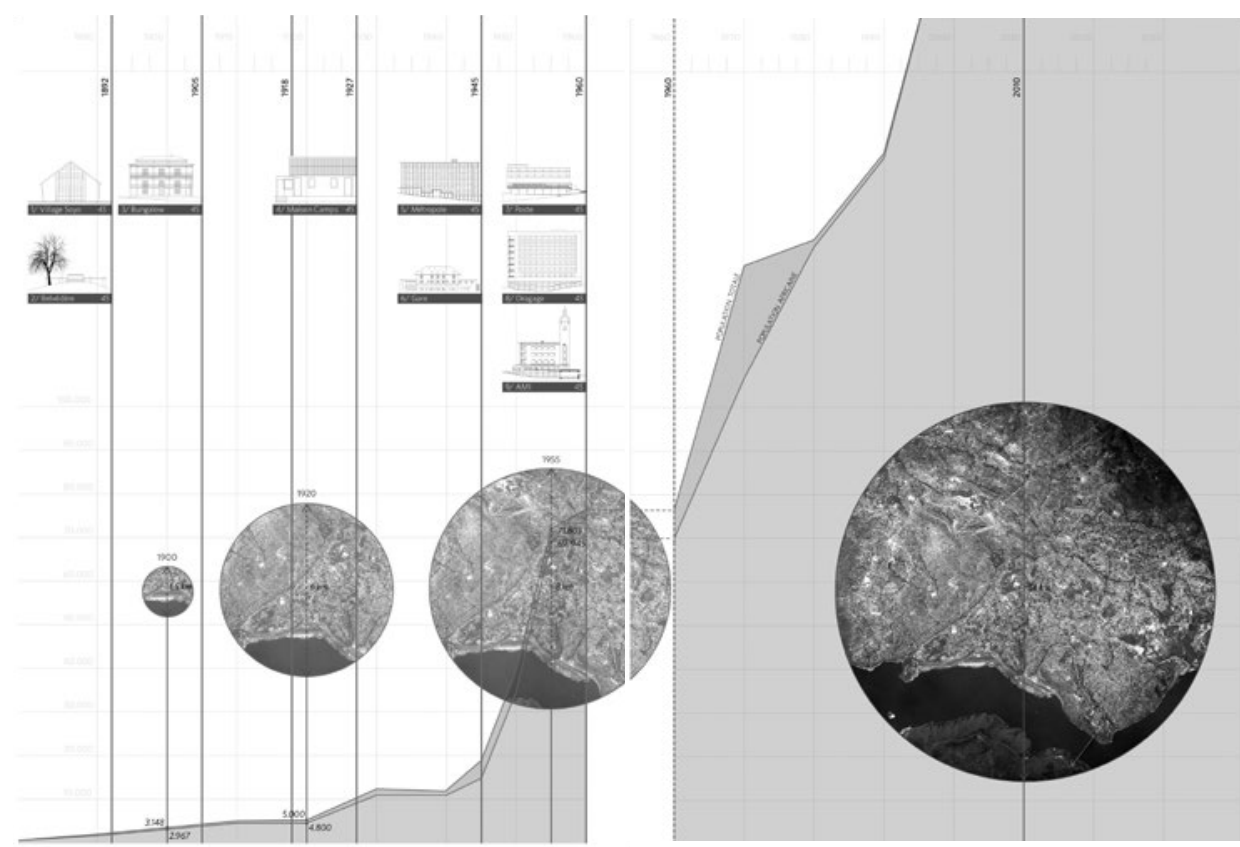

Figure 3: The spatial development of the port city of Matadi, showing the expansion of the urban territory in relationship to the growth of the city's population, and presenting some of the key architectural structures from the different time periods in the colonial era. Scheme prepared by Luce Beeckmans, which will be included in the forthcoming historical atlas of Matadi (Lagae et al., 2019).

generational conversation, a lesson already learned during the 2007 UNIKIN-workshop, when we had explicitly invited junior scholars from various backgrounds to present their work for a broad audience of peers and more established researchers. In the following years, Sabakinu became a crucial interlocutor for the research conducted under Lagae's supervision at UGent in the context of Congo related research seminars, master dissertations, and PhD research projects. ${ }^{5}$ From the UGent perspective, it has been extremely beneficial to collaborate over the last ten years with someone who is very knowledgeable on a wide and sometimes almost forgotten scholarly literature, dealing not only with Congo but more broadly with Africa as a whole. For the Matadi-project, for instance, Sabakinu provided access to important literature on Congo's economic past, including colonial reports and trade bulletins, but also to comparative material allowing us to contextualize the Matadi case within a wider network of African port cities. A more

5 Since 2007, two $\mathrm{PhD}$ dissertations in which Congo is addressed have been completed at the Department of Architecture and Urban Planning (Beeckmans, 2013; De Raedt, 2017), while three Congo-related PhD dissertations are currently forthcoming (Boonen, 2019; Fivez, 2020; De Nys-Ketels, 2020). Since 2005, sixteen Congo-related master dissertations have been produced at the Department of Architecture and Urban Planning, most of which will be mentioned below except for the following ones: Vermeersch, 20II; Vandamme, 2013; Kaisin, 2016; Van Craenenbroeck, 20I6; Camerlinck, 2017. 
recent master dissertation of Congo's road infrastructure (Heindryckx, 20I6) was greatly enriched by gaining quick access to references regarding the role of specific colonial enterprises as well as of missionary congregations in the regions under investigation, and pointing out the importance of issues of land tenure in colonial Africa, a topic that requires further investigation. More generally, the ongoing conversation with Sabakinu has also been crucial in raising awareness among UGent researchers of the risks associated with working mainly, or even exclusively, with sources found in Belgian archives. His support in making fieldwork possible for both master students and $\mathrm{PhD}$ candidates has been extremely important. For the critical inquiry of the 'politics of design' regarding school building programs in post-independence Africa/Congo, conducted by Kim De Raedt in the context of her recently submitted PhD dissertation (De Raedt, 2017), for instance, Sabakinu's support was fundamental in the tracing of former members of the Ministry of Education as well as heads of educational institutes who were able to shed light on the Congolese tactics and agency when dealing with the funding bodies such as the World Bank, the European Development Fund or Unesco.

The fact that since 2007, a number of master students, $\mathrm{PhD}$ candidates and some postdoc researchers of Lagae's research unit at UGent have been part of the ongoing conversation and in most cases have also spent time in DR Congo to conduct fieldwork, has allowed Sabakinu and the staff and students of UNIKIN's History Department to come into contact with new research questions and sometimes overlooked archival collections, both in Belgium and in Congo, which local historians and scholars could also engage with. ${ }^{6}$ Moreover, this younger generation of architectural scholars has demonstrated a strong capacity to work with visual sources and especially to produce detailed and innovative mappings of buildings, cities and even larger landscapes for cases such as Kinshasa (Van Hulle, 2009; Kennivé \& Van Coster, 2012), Lubumbashi (see above), Matadi (Weyers, 2005), Mbandaka (Claeys, 2009), Kisangani (Aelvoet, 20I0; Lierman, 20II), Yangambi (Keymolen et al., 20I5), and the Bas-Congo region (Vandepoele \& De Ruyter, 20I8). This has opened up new avenues for engaging with and communicating on urban history research in DR Congo, and has stimulated the local debate on the need to work towards new (hi)stories of specific sites and cities. In recent years, UNIKIN students have started to research for master dissertations on related topics, such as the ongoing inquiries of the history of Kinshasa's different neighbourhoods, of the sacred city of Nkamba, Simon Kimbangu's birth place, or of the role of customary chiefs in the spatial organization of the peri-urbain areas of Kinshasa. Already in the context of the 2005 Tervuren exhibition, a local scholar initiated a study on the relationship between space and society in the city of Kisangani (Lanza 2005), which she is currently pursuing in the context of PhD research and that in approach is related to a 2005 inquiry of Boma, the first capital city of

6 Over the last ten years, substantial archival research has been done in the Brussels-based Africa Archives, the collections of the Royal Museum of Central Africa, as well as particular funds in the State Archives. In Kinshasa, important archival findings were made in the Archives Nationales du Congo in Kinshasa, and, recently, also in the archives of the ONATRA, the Office National du Transport. In September 2017, the very important, yet overlooked archival fund of Safricas, one of the major constructions companies, active in Congo since the I920s, was traced by UGent PhD candidate Robby Fivez. 


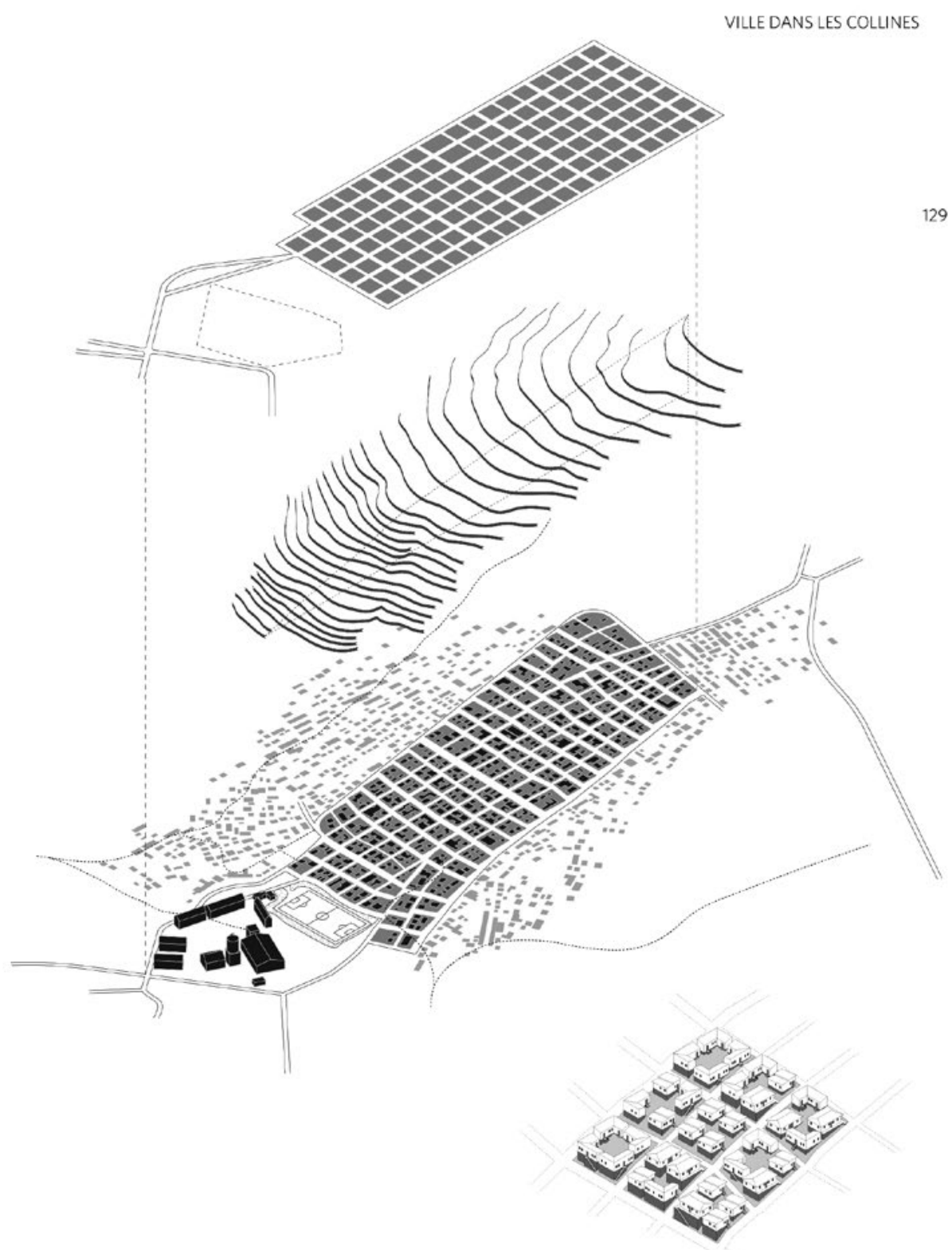

Figure 4: A scheme illustrating the spatial organization of the "cite indigène" of Bruxelles Nord in Matadi, based on plan drawn in the 1930s by the Brussels' based technical services of the Ministry of Colonies. The projection of a grid-plan and type-houses on a hilly landscape with a very complex topography resulted in strange and non-efficient situations. Drawing by Sam Lanckriet, 2015, which will be included in the forthcoming historical atlas of Matadi (Lagae et al., 2019). 
the Congo Free State (Khonde 2005). Urban history topics have been included in seminars of the Chaire d'Histoire de la Population africaine at UNIKIN. Yet, the significant drop in student population at UNIKIN's History Department over the last decades, resulting a quite limited numbers of students and staff today, has formed an obstacle to fully taking advantage of this opportunity on the Congo side, all the more since some of the junior researchers are now conducting their research in the USA or in South Africa.

In what follows, we will briefly sketch out some aspects of such spatialized (hi)stories for the cities of Kinshasa and Matadi, and illustrate how, in our collaborative work, we have made efforts to target various kinds of audiences. For if we share, as will come clear below, a strong belief in the fact that 'history matters' when thinking about the Congolese city, we are also convinced that the urgency of this message should be communicated well beyond the confines of the academy.

\section{Documenting Kinshasa's postcolonial urban landscape and architectural heritage}

An important part of our collaboration has been concerned with the city of Kinshasa, Congo's capital. city. It has involved both historical research on the spatial development of the city and inquiries into the city's built heritage. The latter took place in the context of a project on Kinshasa's patrimoine urbain, initiated in 2009 by Bernard Toulier, who at the time acted as Conservateur général du patrimoine of the French Ministry of Communication and Culture. The project involved the selection of about I50 heritage sites in Congo's capital city, for which documentation was compiled and a preliminary analysis of their current situation and state was conducted. In order to maximize the outreach of the results obtained, a dedicated website was produced, as well as a monograph co-edited by Lagae and to which, among others, Sabakinu and Beeckmans contributed (Auber et al., 2010; Toulier et al., 2010). Our previous conversation on Kinshasa's urban history proved crucial at various stages of the project. First, some significant changes to the initial selection of sites was made in dialogue with a team of local consultants, in which Sabakinu and Leon de Saint Moulin played a prominent role. It resulted in shifting the original strong focus on architectural highlights to an approach that also took into consideration urban memory sites and parts of the city where local, African agency was very palpable in the making and shaping of the city. In the end, several infrastructures were included in the survey that were crucial components of a segregated colonial urban society, such as the Canal Cabu or the Rotonde radiophonique along the Avenue Kasa Vubu, while explicit mention was made of the Village du chef $\mathrm{Ngandu}$, situated in a peripheral area of the city, as an exemplary site where so-called customary land regulation had been crucial in placemaking both in the past and the present. The conversation also resulted in a shift in the project's main agenda: in the end, we no longer claimed to produce a survey of patrimoine urbain, which lists the prime heritage sites of the city, but rather we opted for a presentation that would help people grasp and make sense of the complex urban landscape of Kinshasa, a city one can read both as a patchwork and a palimpsest (Lagae, 20I0). To that end, close attention was given to documenting the development of the city's urban form via a series of newly produced maps that illustrated how Kinshasa's spatial organization 


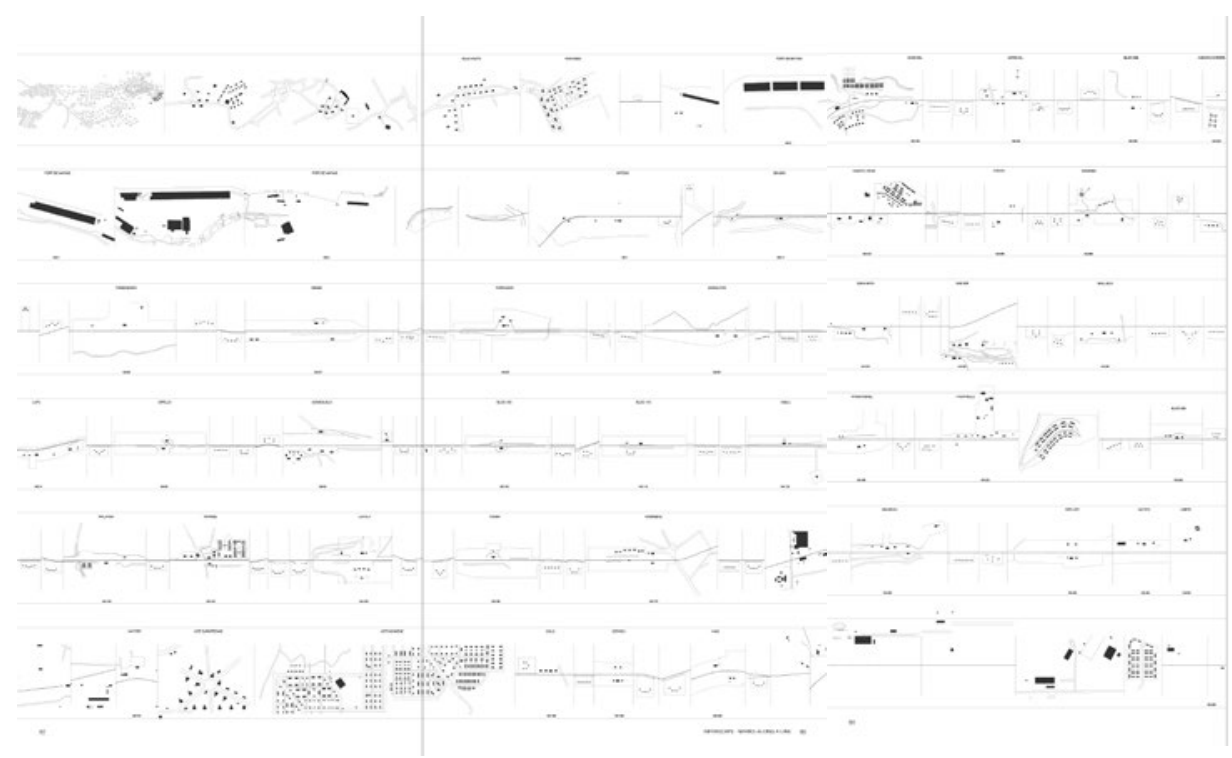

Figure 5: A diagram showing the footprint of every building and built infrastructure of the OTRACO (Office des Transports du Congo) along the Matadi-Kinshasa railway line. This diagram is a redrawn version on an undated archival document [probably late 1950s], found in the OTRACO-archives in Kinshasa in September 2017, which is still used for maintenance purposes by the railway company. Pages from Vandepoele \& De Ruyter, 2018: 82-83.

was both the result of colonial urban planning practices based on the principle of racial segregation and of ad hoc and pragmatic ways of dealing with local constraints of the actual site, such as hydrography or topography (Toulier et al., 2010).

In subsequent work, this approach has been refined, first in a display entitled 'Mapping Kinshasa', shown in 2010 at the Afropolis-exhibition in the Völkerkunde Museum in Cologne, Germany. It was a first attempt to present the city's spatial development by focusing on six organizing urban structures and how these have developed over time, a theme explored in a master seminar at UGent (Department of Architecture UGent 2010), then, in an architectural guide for Kinshasa co-edited by Lagae and Toulier (2013), for which Sabakinu produced an important reflection on the notion of 'built heritage', in which he argued for bringing the debate to a broader local audience, thinking in particular of the younger generation of écoliers. While a large part of the guide was based on earlier historical research, one chapter in particular drew directly on the work of a very insightful historical atlas produced in 2012 by two UGent master students on the Avenue Kasa-Vubu, arguably one of the most interesting streets in Kinshasa, to gain a nuanced understanding of the growth of a segregated city (Kennivé \& Van Coster, 2012; Lagae et al., 2016b). And here again, the work was significantly enriched by the fact that these two students were able to complement their important findings in Belgian archives with substantial material traced in local archives in Kinshasa and fieldwork observations in a challenging urban area, made possible thanks to the guidance and support from UNIKIN. 
Currently, our collaborative work on Kinshasa continues in the context of a FWO-funded research project dealing with hospital infrastructure in DR Congo, which has allowed the connection between Sabakinu's expertise on medical history with, on the one hand, architectural history research on hospital typologies and bureaucratic building procedures within the colonial administration and, on the other, with an anthropological analysis of spatial regimes of governmentality and of informal practices which have emerged in hospital sites over time (FWO G045015N, 2015-2019). The first important results have been obtained with regard to the Hôpital Mama Yemo, the former hospital for Africans situated in the city center of Kinshasa, the origin of which goes back to the early I920s. Through archival work in Belgium, the construction history of the hospital complex has been documented in great detail, and thus has provided local stakeholders with important data on the building stock as well as on how the urban situation of the complex has changed over time (Geenen et al., 20I6). Conducting extensive fieldwork and setting up conversations with a variety of local informants was crucial to gaining an understanding of how the specific spatial organization of the hospital complex according to the type pavillionnaire, a typology that had been common in Europe since the late $19^{\text {th }}$ century and was 'exported' to colonial territories (Mésenge, 20I0; Chang, 20I6), in fact made it possible for very localized practices of dealing with sickness to take root in the complex. For one thing, the pavilion-typology facilitated the presence on site of the garde-malade, a person accompanying a patient in order to provide logistic support (cooking, bringing medicines, etc.). But fieldwork also indicated that we need to fundamentally question the idea that the Hôpital Mama Yemo forms an isolated enclave in the city center. On the contrary, it was found that it actually functions as one of the major zones de passage for those Kinois going from the market to the main bus stops along the Boulevard du 30 juin, resulting in intriguing tactics at the hospital gates of gaining access into and being able to leave the site (Geenen \& De Nys Ketels, 20I8). As such, this research is an important reminder not to take boundary walls at face value and see them as pure instruments of exclusion and inclusion, but rather, as landscape architect Oles has argued, as "places of truck, of interaction and exchange" (Oles, 2015).

\section{Mapping the history of a segregated port city: Matadi}

Apart from Kinshasa, our collaborative work has mainly focused on another urban center in DR Congo: Matadi, the port city. As indicated above, Matadi was part of the first FWOfunded project that started in 2009, but it is only now that we are actually in the final stage of a project that has become much larger than anticipated, and which has started to touch on very different dimensions, resulting in a variety of outcomes which target different audiences. One very specific outcome was an exhibition display produced in 2009-20II for the MAS, Museum aan de Stroom, Antwerp. Invited by the MAS's Africa curator, Els De Palmenaer, to work on the relationship between the port cities of Antwerp and Matadi, we quickly decided it would make more sense to tell the story of that relationship not by focusing on colonial goods entering the metropole via Antwerp nor by following the trajectory of Belgian colonials from Antwerp to Matadi, but rather by bringing to the fore one group that in a very peculiar way embodies the connection between the two cit- 
ies: the Congolese seafarers. To that end, we spent two fieldwork missions in Matadi in 20Io, interviewing (former) Congolese seafarers and documenting the memories of how they experienced their time in Antwerp, complementing this information with an -albeit incomplete- spatial mapping of the specific places in Antwerp that testify of their -temporary- presence in the city. This material has been part of the permanent display in the MAS, in the section on 'Antwerp World port' (Lagae et al., 2012), but has also served as the basis for academic output (e.g. Lagae \& Sabakinu, 20I8).

Over the last ten years, we have simultaneously been conducting substantial archival work in order to investigate in great detail some of the key buildings in Matadi and the spatial development of Matadi's urban form, and this work complements a preliminary study into these topics conducted by a UGent master student (Weyers 2005). Through this, we have gained insight into how the relation between the city and the port infrastructure has

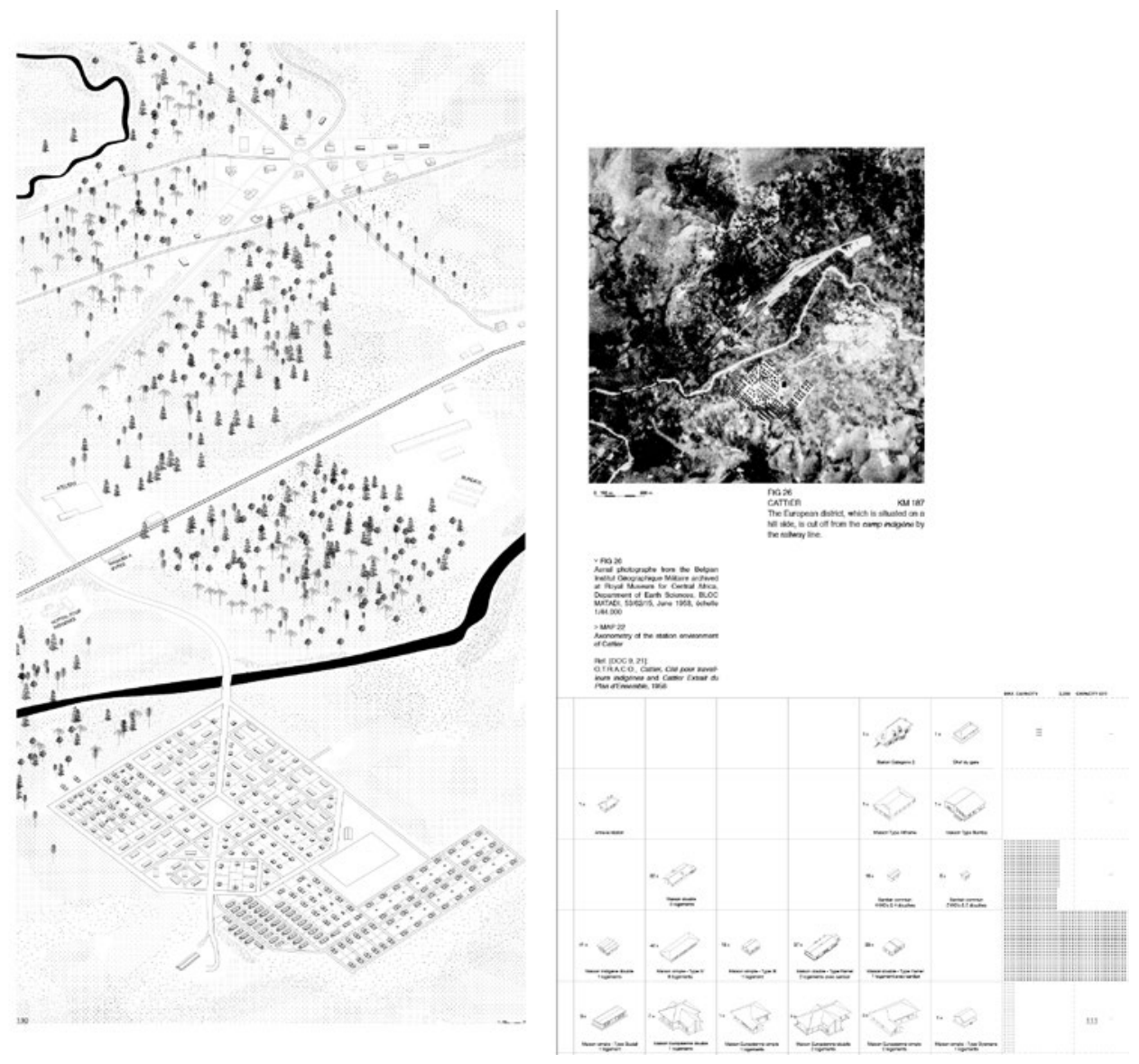

Figure 6: Spatial mapping of the Cattier-site along the Matadi-Kinshasa railway line, illustrating the use of type-buildings for the railway station, storage facilities, housing of the European agents and the accommodation of the workers of OTRACO (Office des Transports du Congo), the colonial railway company. Pages from Vandepoele \& De Ruyter, 2018: 110-111. 
changed over time, as well as how the principle of a segregated city was implemented in colonial Matadi. Our research, not surprisingly, revealed that many parallels can be drawn with what happened in Kinshasa, because of the standard guidelines and models of colonial urban planning that were applied all over the Belgian Congo. But Matadi proved a powerful case, revealing the limits of these guidelines and models, as the site chosen to found the port city proved very challenging to implement standardized city plans, construct type buildings (from houses to schools to hospitals), or introduce urban infrastructures such as an urban sewage system because of the extreme topography, coupled with a severe tropical climate. The outcome of this collaborative research, that also draws heavily on Sabakinu's I98I PhD on Matadi, will result in the course of 20I9 in the publication of a historical atlas of Matadi (Lagae et al., 20Igb). For this forthcoming publication, we collaborated closely with Luce Beeckmans and two former UGent students in order to produce an appealing visual narrative presenting Matadi, first, as a port city on the Congo river and, second, as a complex segregated colonial city erected in the hills. This narrative addresses explicitly aspects of the provision of workers' housing and urban sanitation (Lagae et al., 2019a), as well as of the policing of a segregated urban environment, a dimension that has recently gained currency in the field of colonial studies (Lagae \& Sabakinu, 20I7; Blanchard et al., 2017). Through this work, we aim to contribute to the new strand of historiography on colonial cities that pays attention to the messiness of implementing urban segregation, an approach Carl Nightingale advocates in his seminal book on the topic (20I2).

In addition we believe that this historical research is also relevant for contemporary Matadi and it has already been important in the context of another project, commissioned by the Congolese Ministry of Housing and Planning, with regard to the urban development of six secondary cities in DR Congo, including Matadi, to which Lagae contributed as a consultant (Hydea, 2015). This project asked for the development of a methodology which local authorities could use to manage their building stock and plan how this patrimoine urbain might inform future urban development. While this project is in essence about contemporary urban governance, it was decided to bring a strong historical component to it, in order to show that 'history matters' when thinking and planning the future of Congolese cities. If one is to define priority strategic urban projects, the project team argued, it is crucial to have a sound understanding of the origin of urban form and of its development over time. Unfortunately, it was a message that seemed to fall on deaf ears in the technocratic oriented milieu of the clients and the local representatives of the World Bank, which provided the funds, though this attention of the historical dimension was picked up with some enthusiasm at the local level, as became clear during the visits to these cities as well as during a workshop with local administrators of the six selected cities which took place in Matadi in autumn 2015 and resulted in a first online database (Urbacongo, 2015).

\section{What's next?}

The two examples given above of Kinshasa and Matadi provide a select overview of the kind of work on urban history that has been produced in a collaborative dialogue between UGent and UNIKIN over the last ten years and which includes not only both authors of 
this article, but more broadly, different researchers from UGent (in particular from its Department of Architecture and Urban Planning) and from UNIKIN, and more specifically its History Department. As we have shown, this collaborative work has led to a series of different outcomes, some of which are academic in scope (articles, conference papers, books and book chapters, master dissertations and $\mathrm{PhDs}$ ), while others deliberately were developed to target a broader audience: exhibitions in both Belgium and DR Congo, presentations for local stakeholders and policy makers, conferences in the cultural arena, etc. We have explicitly opted to publish a substantial part of this work in French, rather than using the lingua franca of academic research, English, as we deem it crucial that a wide Congolese/African audience can easily access the results of our research.

Currently, several plans are on the table to continue this conversation, and also to broaden it beyond the strict field of urban history. In recent years, very promising master dissertations have been produced on colonial landscapes and infrastructures: the road network has proven to be an overlooked subject that is full of potential (Heindryckx, 20r6; Heindryckx, 20I7). Recently two UGent-students produced an atlas of the Bas Congo region, using the Matadi-Kinshasa railroad as the backbone for a mapping of the transformation of particular landscapes along the trajectory, illustrating how the railroad is, in fact, an infrastructural project with a very wide footprint (Vandepoele \& De Ruyter, 20I6). Finally, in the context of an ongoing FWO-project that looks at the colonial and postcolonial Congo from a Construction History-perspective (FWO G053215N, 2015-2019), we are currently discovering a number of building typologies and infrastructures that beg further in-depth investigation, such as hydraulic dams, breweries, cement factories, silos for the storage of various resources and workers' camps, the latter being a subject on which already some groundbreaking research has been done (De Meulder, I996). This research raises new research questions with regard to the introduction of specific building technologies in Congo, such as the use of reinforced and pre-stressed concrete (Fivez, 20I7), or the international flows of building expertise that informed construction in Congo. But more importantly, it also urges us to think in more profound ways on fundamental issues such as the distribution of (forced) labor on building sites (Lagae \& Van Craenenbroek 2015; Fivez, 2018) or the resource extraction linked to building activities, and the legacy of "imperial debris" it created (Stoler, 2013).

In other words, there is still more than enough on our plate to continue our collaborative conversation for at least another decade. But, as was already suggested at the beginning of this chapter, one of the challenges remains how to extend our collaborative conversation beyond the disciplines that have been involved so far (socio-economic history, architectural/urban planning history and anthropology) to other fields such as Conflict and Development Studies, Medicine and Law. It is here that GAP offers a forum from which we could benefit more, as our collaborative work neatly fits the platform's agenda. For if we took one lesson from the 2007 workshop on urban history we co-organized at the UNIKIN in Kinshasa, it is that the most exciting, if challenging, context to work in is one where it is possible to start a dialogue between North and South across the boundaries of disciplines, academic cultures and generations. 


\section{References}

Aelvoet, S. (2010). Beeldkroniek van Kisangani / Stanleyville. Een ruimtelijke en architecturale analyse van een koloniale stad. Unpublished master dissertation, Ghent University.

Anderson, D.M. \& Rathbone R. eds. (2000) Africa's Urban Past. Oxford/Portsmouth: James Currey/ Heinemann.

Auber, O., Toulier, B., Lagae, J., Gemoets, M. (2010) www.wikinshasa.org

Auber, O., Lagae, J. \& Graz, C. (2015) http://www.urbacongo.info/index.php/INVENTAIRE_DU_ PATRIMOINE_DE_RD_CONGO

Baloji, S. (2018) A Blueprint for Toads and Snakes [exhibition catalogue]. Amsterdam: Framer/Framed [with a contribution by Johan Lagae \& Sofie Boonen]

Beeckmans, L. (2013) Making the African City. Dakar - Dar es Salaam - Kinshasa 1920-1980. Unpublished $\mathrm{PhD}$ dissertation, Rijksuniversiteit Groningen.

Blanchard, E., Bloembergen, M. \& Lauro, A. (2017) Policing in Colonial Empires. Cases, Connections, Boundaries (ca. 1850-1970). Brussels: Peter Lang Verlag.

Boonen, S. (2009) Lubumbashi/Elisabethstad. De morfologie van een kosmopolitische stad. Unpublished master dissertation, Ghent University.

Boonen, S. \& Lagae, J. (2015a) A city constructed by « des gens d'ailleurs ». Urban development and migration policies in colonial Lubumbashi, I9IO-I930". Comparativ. A Journal of Global History and Comparative Studies, (4), 5I-69.

Boonen \& Lagae (2015b) Scenes from a changing colonial "Far West". Picturing the early urban landscape and colonial society of cosmopolitan Lubumbashi, I9IO-I93I. Stichproben. Wiener Zeitschrift für Kritische Afrikastudien, I5 (28): II-54.

Boonen, S. (2019) Fixer, franchir et reconsidérer les limites. Gouvernance et développement urbain à Élisabethville coloniale ( $\mathrm{RD}$ Congo). Forthcoming PhD dissertation, Ghent University.

Camerlinck, L (2017) The Construction of the Colonial Welfare State. Tracing design strategies in the Belgian Congo's Ten Year Plan, 1949-1959. Unpublished master dissertation, Ghent University.

Çelik, Z. (1997) Urban Forms and Colonial Confrontations: Algiers under French Rule. Berkeley: University of California Press.

Chang, J.-H. (2016) A Genealogy of Tropical Architecture. Colonial Networks, Nature and Technoscience. Abingdon: Routledge, Abingdon.

Claeys, S. (2009) Mbandaka/Coquilhatstad, Democratische Republiek Congo. Beeldkroniek van een koloniale stad. Unpublished master dissertation, Ghent University.

Coquery-Vidrovitch, C. (1993) Histoire des villes d'Afrique noire. Des origins à la colonization. Paris: Alban Michel.

De Keyzer, C. \& Lagae, J. (2010) Congo belge (en images). Tielt: Lannoo [with contributions by Sabakinu Kivilu, J. \& Hayes, P.]

De Meulder, B. (1996). De kampen van Kongo. Arbeid, kapitaal en rasveredeling in de koloniale planning. Antwerpen: Kritak.

De Nys-Ketels, S. (2009) Koloniaal beleid en stedelijke ruimte in een Congolese stad. De wijk Kenya in Lubumbashi, Congo. Unpublished master dissertation, Ghent University.

De Nys-Ketels, S. (2020). Urban landscapes of colonial/postcolonial health care. Towards a spatial mapping of the performance of hospital infrastructure in Kinshasa, Mbandaka and Kisangani (DR Congo) from past to present (1920-2014). Forthcoming PhD dissertation, Ghent University.

De Raedt, K. (2017) Policies, People, Projects. School building as development aid in postcolonial Sub-Saharan Africa. Unpublished $\mathrm{PhD}$ dissertation, Ghent University.

De Saint Moulin, L. (2010) Villes et organisation de l'espace au Congo (RDC). Cahiers africains (77). 
Department of Architecture and Urban Planning Ghent University [Luce Beeckmans, Johan Lagae \& Guy Châtel] (2010) Mapping Kinshasa. In K. Pinther, L. Fösster \& C. Hanussek, Afropolis. Stadt, Medien, Kunst [exhibition catalogue, Rautenstrauch-Joest-Museum - Kulturen der Welt Köln] 26o26I (English edition 2013).

Etambala, Z. \& Mabiala, P. eds. (20I6) La société congolaise face à la modernité. Mélanges eurafricains offerts à Jean-Luc Vellut. Cahiers africains (89).

Fenaux, C. (2010) Het Office des Cités Africaines in Lubumbashi: Ruashi. Architecturale analyse en studie van de toe-eigening van een Congolese woonwijk uit de jaren 1950. Unpublished master dissertation, Ghent University.

Fivez, R. (2017) Exporting Prestressed Concrete to Africa. The Construction of the Bata 300 Shoe Factory in Kinshasa, DR Congo, 1962-1965. In High Tech Concrete: Where Technology and Engineering Meet. Proceedings FIB Symposium. Springer.

Fivez, R. (2018) «Elle pousse, la Capitale Champignon! » Questioning skill in the Belgian Congo's building industry. Proceedings of the Sixth International Congress on Construction History held in Brussels, July 6-13, 2018, CRC Press/Balkema, Taylor \& Francis Group, 273-28o.

Fivez, R. (2020) “Tout le Congo est un chantier". Re-assessing Congo's architectural history from 1918 till 1975 through a construction history approach. Forthcoming $\mathrm{PhD}$ dissertation, Ghent University.

Freund, B. (2007) The African City. A History. Cambridge: Cambridge University Press.

FWO Go78609N (2009-2012) City, architecture and colonial space in Matadi and Lubumbashi, Congo. A historical analysis from a translocal perspective. Main supervisor: Johan Lagae; co-supervisors: Baz Lecocq (Ghent University); Donatien Dibwe (UNILU, DR Congo); Jacob Sabakinu Kivilu (UNIKIN, DR Congo). Main researcher: Sofie Boonen (PhD).

FWO G045015N (2015-2019) Urban landscapes of colonial/postcolonial health care. Towards a spatial mapping of the performance of hospital infrastructure in Kinshasa, Mbandaka and Kisangani (DR Congo) from past to present (1920-2014). Main supervisor: Johan Lagae; co-supervisors: Koen Stroeken \& Luce Beeckmans (UGent), Jacob Sabakinu Kivilu (UNIKIN, DR Congo). Main researcher: Simon De Nys-Ketels (PhD) \& Kristien Geenen (postdoc).

FWO G053215N (2015-2019) “Tout le Congo est un chantier". Re-assessing Congo's architectural history from 1918 till 1975 through a construction history approach. Main supervisor: Johan Lagae ; co-supervisors : Rika Devos (ULB), Luc Taerwe (UGent) \& Jacob Sabakinu Kivilu (UNIKIN, DR Congo). Main researcher: Robby Fivez (PhD).

Geenen, K., De Nys-Ketels, S., Lagae, J. \& Sabakinu Kivilu, J. (2016) Historique des bâtiments de l'Hôpital Provincial Général de Kinshasa (ex Mama Yemo), brochure, 32 pags., UGent.

Geenen, K. \& De Nys Ketels, S. (2018) Pedestrian Itineraries in Kinshasa: On Shortcuts, Permeable Walls and Welded Shut Gates in a Former Colonial Hospital. Space and Culture.

Heindryckx, L. (20I6) Forging Congo's road network. Scenes of dissonance within the colonial project. Unpublished master dissertation, Ghent University.

Heindryckx, L. (2017) Weginfrastructuur als lens voor het koloniale bouwproject. Agora, 33 (4): 3I-34.

Hydea (2015). Rapport finale de la Mission de realization d'une étude en vue d'élaborer un canevas pour la gestion du patrimoine de chacune des villes participantes du Projet de développement urbain, République Démocratique du Congo, dans le cadre du Projet de développement urbain (PDU) - Don IDA 8420-DRC (Banque Mondiale). Rapporteurs : Lagae, J., Graz, C. \& Auber, O. in coll. with Archplan International \& Urbaconsult.

Hunt, N.R. (1999) A Colonial Lexicon of Birth Ritual, Medicalization, and Mobility in the Congo. Durham: Duke University Press.

Kaisin, S. (20r6) Koloniale landschappen van gezondheid: een typologische analyse van de hospitaalarchitectuur in DR Congo in historisch perspectief. Unpublished master dissertation, Ghent University.

Kennivé, R. \& Van Coster, R. (2012) Een kritische historische atlas van de Avenue Kasa Vubu in Kinshasa, Congo. Unpublished master dissertation, Ghent University. 
Keymolen, K., Verraes, A. \& Deltomme T. (2015) A Forgotten Past: Yangambi. The Eldorado of Science. Unpublished master dissertation, Ghent University.

King, A.D. (1984) Colonial Architecture Re-visited: Some Issues for Further Debate. In K. Ballhatchet \& D. Taylor (eds.) Changing South Asia: City and Culture. London: University of London.

Khonde Ngoma di Mbumba, C. (2005) Boma. Première capitale de l'Etat Indépendant du Congo. Kinshasa : L'Harmattan.

Kostoff, S. (1992) The City Assembled. The Elements of Urban From Through History. Boston: Bulfinch Press, Boston.

Lagae, J. (2002) "Kongo zoals het is". Drie architectuurverhalen uit de Belgische kolonisatiegeschiedenis 1920-1960. Unpublished PhD dissertation, Ghent University.

Lagae, J., De Keyser, T. \& Vervoort, J. (2005) Boma 1880-1920. Colonial Capital City or Cosmopolitan Trading Post?. Gent/Tervuren: A\&S Books/KMMA [cd-rom].

Lagae, J. (2010) Le territoire urbain de Kinshasa : patchwork et palimpsest. In Toulier, B. et al. (eds.) Kinshasa. Architecture et Paysages urbains. Paris : Somogy Editions d'art, pp. 8-2I.

Lagae, J., Boonen, S. \& Liefooghe, M. (2013) Fissures dans le " cordon sanitaire ». Architecture hospitalière et ségrégation urbaine à Lubumbashi, I920-I960. In M. Amuri Mpala-Lutebele (ed.), Lubumbashi. Cent d'ans d'histoire. [Actes du Colloque internationale 'Lubumbashi, 9-II septembre 2010, Campus de l'Université de Lubumbashi]. Paris : L'Harmattan, pp. 247-26r.

Lagae et al.20I2 MAS book Johan Lagae, J., De Palmenaer E. \& Sabakinu Kivilu, J. (2012) Antwerp. 6. Colonial Port. In J. Vrelust (ed.) Antwerp. World Port. On Trading and Shipping. Antwerp: BAI/MAS, pp. IOI-I 25

Lagae, J. \& Toulier, B. eds. (2013) Kinshasa . Ccollections villes et architecture. Brussels : CIVA.

Lagae et al. 2013 = Johan Lagae, Sofie Boonen \& Maarten Liefooghe, "Fissures dans le " cordon sanitaire ". Architecture hospitalière et ségrégation urbaine à Lubumbashi, I920-1960", in Maurice Amuri Mpala-Lutebele (ed.), Lubumbashi. Cent d'ans d'histoire [Actes du Colloque internationale 'Lubumbashi, cent ans d'histoire.Littérature, cultures urbaines, débats intellectuels', 9-II septembre 20ro, Campus de l'Université de Lubumbashi], L'Harmattan, Paris, 2013, pp. 247-26I, ISBN 978-2-343-01399-2

Lagae, J. (2015) "Congo as it is?" Curatorial reflections on Using Spatial Urban History in the Memory of Congo: The Colonial Era Exhibition. In A. Coombes \& R. B. Phillips (eds.), Museum Transformations, vol. 5 in the series International Handbooks of Museum Studies. Chichester: Wiley Blackwel, pp. 157I80.

Lagae, J. \& Van Craenenbroeck, L. (2015) "Congobéton Léopoldville. Congés payés du I/I/57 au 3/12/57". Postwar architecture, Construction Work and local Labor in a Belgian colony, ABE Journal [online journal] (8). http://journals.openedition.org/abe/2797

Lagae, J., Boonen, S. \& Dibwe D. (2016a) M(g)r. De Hemptinne, I presume? Transforming Local Memory Through Toponymy in Colonial/Post-Colonial Lubumbashi, DR Congo. In L. Bigon (ed.) Place Names in Africa, pp. I77-I94. Springer.

Lagae, J., Beeckmans, L., Kennivé, R. \& Van Coster, R. (2016b) Vers une radioscopie de la ville coloniale. Episodes dans la génèse de l'Avenue Kasa-Vubu, Kinshasa. In Z. Etambala \& P. Mabiala (eds.) La société congolaise face à la modernité (1700-2010). Mélanges eurafricains offerts à Jean-Luc Vellut, pp. 309343. Paris/Tervuren : L'Harmattan/MRAC.

Lagae, J. \& Sabakinu Kivilu, J. (2017) Policing the City. Colonial urban planning and the politics of order in the port city of Matadi, DR Congo, 1928-1960. Paper presented at the $2^{\text {nd }}$ International Conference on African Urban Planning, Lisbon, 7-8 September 2017.

Lagae, J. \& Sabakinu Kivilu, J. (2018) « Good grief. Is Antwerp city where the jungle begins now?” Urban traces and Congolese memories of exclusion in the port cities of Antwerp and Matadi (Congo), 1920-1960. Paper presented at the EAUH Conference, Rome, 29 August - I September 2018. 
Lagae, J., Sabakinu Kivilu, J. \& Beeckmans, L. (2019a) 'Pour Matadi la question [de la ségrégation] est encore plus grave qu'ailleurs': The making and shaping of a Congolese port city during the interwar years. In J. Vanderlinden \& P. Petit (eds.), Proceedings Conference Congo in the Interwar Years, Brussels, March 2106, ARSOM/KAOW (in print)

Lagae, J., Sabakinu Kivilu, J. \& Beeckmans, L. (2019b) Atlas Matadi. Radioscopie d'une ville portuaire au Congo belge. Antwerp/Tervuren : BAI Books/RMCA.

Lanza, H. (2005) Stanleyville, ville cosmopolite : la localisation des différents groupes dans l'espace urbain. In J.-L. Vellut (ed.) La Mémoire du Congo. Le temps colonial, op. cit., pp. 99-I03.

Lierman, S. (20II) De Office de Cités Africaines in Kisangani: een stedenbouwkundig onderzoek naar genese en toe-eigening van een woonwijk uit de jaren 1950 in Afrika. Unpublished master dissertation, Ghent University.

Mabiala, P. ed. (2004) La nouvelle histoire du Congo. Mélanges eurafricains offerts à Frans Bontinck C.I.CM. Cahiers Africains (65-67).

Mésenge, C. ed. (2010) Patrimoine hospitalier d'Afrique : Égypte, Maroc, Sénégal, Bénin. Paris : Riveneuve

Mudekereza, P. (2017) Rue de la Résistance. In Lee, R. et al. (eds.), Things do not exist until you give them a name. Unpacking urban heritage. Dar-es-Salaam: Mkuki Na Nyota, pp. I86-IgI

Nightingale C. H. (2012) Segregation. A Global History of Divided Cities. Chicago: The University of Chicago Press.

Njami, S. ed. (2012) Rencontres Picha. Biennale de Lubumbashi du 13 au 17 octobre 2010. Paris : Filigraines.

Oles, T. (2015) Walls. Enclosures \& Ethics in the Modern Landscape. Chicago: University of Chicago Press.

Sabakinu Kivilu, J. (198I) Histoire de la population et des condition de vie à Matadi de 18go à 1959 . Unpublished PhD dissertation, Université Nationale du Zaïre - Campus de Lubumbashi.

Sabakinu Kivilu, J. (1984) Population et santé dans le processus d'industrialisation du Zaïre. Revue Canadienne des Etudes Africaines, XVIII : 94-98.

Sabakinu Kivilu, J. (I990) Population and Worker Mortality in Western Zaïre ca. I900-I935. In B. Fetter (eds.) Demography from scant evidence. Central Africa in the colonial Era. Boulder: L. Rienner Publishers. pp. 327-347.

Sabakinu Kivilu, J. \& Obotela, N. (forthcoming) Mélanges eurafricains offerts à Léon de Saint Moulin. Cahiers africains.

Salm S. \& Falola, T. eds. (2005) African urban spaces in historical perspective. Rochester/woodbridge: University of Rochester Press.

Stoler A. ed. (2013) Imperial Debris. On Ruins and Ruination, Durham : Duke University Press.

Toulier, B., Lagae, J. \& Gemoets, M. (2010) Kinshasa. Architecture et paysage urbains. Paris: Editions Somogy, Paris [with contributions by Jacob Sabakinu Kivilu, Luce Beeckmans \& Léon de Saint Moulin]

Van Craenenbroeck, L. (20r6) Een Belgisch bouwbedrijf in Congo. De familie Blaton als Compagnie Congolaise de Constructions en als Congobéton van 1949 tot 1975. Unpublished master dissertation, Ghent University.

Vandamme, E. (2013) De architectuur van ontwikkelingssamenwerking: Het Europees Ontwikkelingsfonds en scholenbouw in postonafhankelijk Afrika. Unpublished master dissertation, Ghent University.

Vandepoele, J. \& De Ruyter, F. (2018) Mapping a transforming colonial landscape. An atlas of the Bas-Congo region along the Matadi-Leopoldville railway line. Unpublished master dissertation, Ghent University.

Van Hulle, B. (2009) "Chronique de Léopoldville de 1881-1956". Kritische analyse van het stadsbeeld van Kinshasa op basis van een ongepubliceerd manuscript van Hélène Guillaume (Whyms). Unpublished master dissertation, Ghent University.

Vellut, J.-L. (I974) Guide de l'étudiant en histoire en Zaïre. Kinshasa : Ed. Centre de Recherches Pédagogiques.

Vellut, J.-L. et al. (2005) La mémoire du Congo. Le temps colonial. Gent: Snoeck.

Vellut, J.-L. ed. (2007) Villes d'Afrique. Explorations en histoire urbaine. Cahiers africains (73) 
Vellut, J.-L. (2017) Congo. Ambitions et désenchantements 1880-1960. Paris: Karthala.

Vermeersch, A. (20II) Monografische studie van een in Afrika actieve architect/bureau: Eugène Palumbo. Unpublished master dissertation, Ghent University.

Weyers, E. (2005). Kroniek van de koloniale havenstad Matadi : stedebouwkundige en architecturale ontwikkelingen tussen 1880 en 1960. Unpublished master dissertation, Ghent University.

Wright, G. (I99I). The Politics of Design in French Colonial Urbanism. Chicago: University of Chicago Press. 